\title{
DETECTION OF BRUCELLA ABORTUS DNA IN ILLEGAL CHEESE FROM SÃO PAULO AND MINAS GERAIS AND DIFFERENTIATION OF B19 VACCINAL STRAIN BY MEANS OF THE POLYMERASE CHAIN REACTION (PCR)
}

\author{
Simone Miyashiro ${ }^{1 *}$; Eliana Scarcelli; Rosa M. Piatti ${ }^{1}$; Fabíola R. Campos ${ }^{1}$; Airton Vialta ${ }^{2}$; Lara Borges Keid $^{3}$; \\ Ricardo Augusto Dias ${ }^{3}$; Margareth E. Genovez ${ }^{1}$
}

${ }^{1}$ Instituto Biológico, Vila Mariana, São Paulo, SP, Brasil; ${ }^{2}$ Instituto de Tecnologia de Alimentos, Campinas, SP; ${ }^{3}$ Faculdade de Medicina Veterinária e Zootecnia, Universidade de São Paulo (USP), São Paulo, SP

Submitted: March 31, 2006; Returned to authors for corrections: August 17, 2006; Approved: January 18, 2007

\begin{abstract}
A total of 192 samples of illegal cheese from different regions of the states of São Paulo and Minas Gerais, Brazil, were analyzed for the isolation and detection of Brucella spp. DNA by means of microbiological culture and polymerase chain reaction (PCR), respectively. Samples that yielded positive results were submitted to the analysis of the occurrence of Brucella abortus (biovars 1, 2 e 4), as well as to the differentiation of DNA in B19 vaccinal strain or Brucella abortus field strain using PCR. Although the microorganism was not isolated from any sample, PCR detected 37 positive samples (19.27\%) using genus-specific primers. From these, all (100\%) were Brucella abortus. Differentiation of the strain showed that 30/37 samples (81.08\%) were vaccinal strain B19 and seven (18.92\%) were Brucella abortus field strains. Results showed that diagnostic sensitivity of PCR was greater than that of microbiological culture. The standardization of the reaction for the differentiation of vaccinal and field strains enabled the analysis of all samples positive for Brucella abortus. It is, therefore, a reliable method, also applicable to natural infections caused by the microrganism.
\end{abstract}

Key words: Brucella abortus, B19, PCR, cheese

\section{INTRODUCTION}

Brucellosis is one of the most important and worldwide spread zoonosis (15). In Brazil, brucellosis caused by Brucella abortus is the most prevalent infection. The species is divided into eight biovars: 1, 2, 3, 4, 5, 6, 9 and vaccinal strain B19 $(7,12,16)$. Since 1985, only biovars 1, 2 and 3 have been detected in Brazil (10).

According to the Brazilian Ministry of Agriculture, dairy herds represent $20 \%$ of the total brazilian bovines. Cattle raising occurs mainly in the south and southeast regions of the country, with $69 \%$ of the national production (15). It is estimated that approximately $29 \%$ of the milk produced in the country, and consumed mostly as fluid milk, cheese, sweets and other products, does not meet the legal requirements (9).

B19 is a live, attenuated vaccine used in bovine females, used for prevention of bovine brucellosis, is the only vaccine recommended by the National Plan for Brucellosis and Tuberculosis Control and Eradication [Plano Nacional de Controle e Erradicação da Brucelose e Tuberculose (PNCEBT)], that began in 2001 (2). In the B19 strain, a fragment of $702 \mathrm{bp}$ (base pairs) of gene ery was deleted and this would be the explanation for its sensitivity to erythritol (7).

Diagnosis is an essential part of the PNCEBT program and direct detection methods are very important in the confirmation of outbreak foci, as well as in the characterization of the strain (14). Even in countries where all forms of the disease have been eradicated, continuous surveillance is essential to prevent the reintroduction of the disease (5).

Bricker and Halling (3) described a PCR method called AMOS PCR, which identified and differentiated most of the Brucella species and biovars found in the US (B. abortus bv. 1, 2 and $4 ; B$. melitensis bv. 1, 2 and 3; B. ovis and B. suis bv. 1). The method

*Corresponding Author. Mailing address: Centro de Pesquisa e Desenvolvimento de Sanidade Animal - Instituto Biológico, Av. Conselheiro Rodrigues Alves, 1252 - Vila Mariana - São Paulo, SP. CEP: 04014-002. Tel.: (11) 5087-1721 ou (11) 5087-1791. E-mail: miyashiro@biologico.sp.gov.br 
was based on the fact that the repetitive genetic element IS 711 is exclusive in the genus Brucella and, for most species, at least one copy of the element occurs in a unique species or biovarspecific chromosomal locus. Sangari, García-Lobo and Agüero (17) reported the restriction analysis of the eri region from $B$. abortus 2308 and vaccine $\mathrm{B} 19$ chromosomes, revealing a deletion sequence of about 702 nucleotides in the chromosome of the vaccinal strain. So, they described a PCR method for the differentiation of B19 strain of other B. abortus isolates using two oligonucleotides designed from the DNA sequence of $B$. abortus 2308, one to each side of the endpoints of the deletion found in B19. As expected, these primers sustained the specific amplification of a 1.063 base pairs (bp) from strain 2308 and other B. abortus strains and a $361 \mathrm{bp}$ fragment from B19 strain. Ewalt and Bricker (8) validated AMOS PCR for the same differentiation using a primer pair which amplifies a short sequence (178 base pairs) of the eri gene with one primer that anneals to a region of the eri locus common to B19 and other Brucella species, while the second primer anneals within the $702 \mathrm{pb}$ deletion (4). Therefore, the identification of B19 strain is based on the absence of amplification of this target.

PCR is an option for brucellosis diagnosis. However, few studies have been carried out with field samples in a way to use the reaction as a diagnostic tool (11). In Brazil, in spite of the importance of bovine brucellosis, few studies have been performed for the investigation of different Brucella biovars among bovines (15). The present trial analyzed the presence of Brucella abortus in illegal dairy products from the states of São Paulo and Minas Gerais (Brazil) by comparing the results obtained by means of polymerase chain reaction (PCR) and microbiological culture and developing a hemi-nested PCR reaction efficient in the differentiation of strain B19 in naturally infected dairy samples.

\section{MATERIALAND METHODS}

\section{Samples}

A total of 192 illegal cheese samples were randomly collected in 2001 and 2002, coming from different regions of the states of São Paulo (SP) and Minas Gerais (MG) - Brazil. Types of cheese included 141 samples of Minas frescal type fresh white cheese (59 from MG and 92 from SP) and 51 samples of cured Minas type cheese (18 from MG and 33 from SP).

\section{Standard strains}

- B19. The strain was used in the experimental contamination of cheese for the determination of the analytical sensitivity of PCR and for the confirmation of primer specificity.

- ATCC (American Type of Culture Collection) strains. ATCC B. abortus 544 (bv.1), B. suis 1330 (bv. 1), B. canis LM 6/66, B. ovis $63 / 290$ (bv. 1), B. neotomae $5 \mathrm{k} 33$ (bv. 1) and $B$. melitensis $16 \mathrm{M}$ (bv. 1) samples were used in the confirmation of primer specificity.
- RB51. The strain was used in the confirmation of primer specificity.

\section{Microbiological culture}

Twenty five grams of each cheese sample were homogenized in $100 \mathrm{~mL}$ of Brucella broth (DIFCO), using a Stomacher 80 (Lab System ${ }^{\circledR}$ ) and let to rest for some seconds. Ten microliters of the supernatant were used in the culture, as described by OIE(13).

\section{DNA extraction}

One hundred microliters of the supernatant of the cheese samples were used. Extraction was accomplished by means of commercial reagent DNAzol (Invitrogen) (6). Colonies of the standard strains were resuspended in milliQ water and DNA was extracted by boiling $\left(100^{\circ} \mathrm{C} / 10\right.$ minutes $)$ and after centrifugation (10000 x g/ 2 minutes), the supernatant was used for PCR purpose.

\section{PCR}

The reaction was carried out using DNA extracted with genusspecific primers $\mathrm{B}_{4}$ and $\mathrm{B}_{5}$, which amplified fragments of $223 \mathrm{bp}$, as described by Baily et al. (1). PCR for Brucella abortus was performed in samples positive for Brucella spp., using a pair of primers (BAB and IS 711) described by Bricker and Halling (3), which amplified $498 \mathrm{bp}$ fragments. Modified amplification of DNA was carried out with $14 \mu \mathrm{l}$ of ultrapure water (Millipore), $20 \mu \mathrm{l}$ of Master Mix - Eppendorf (50 mM KCl, 30 mM Tris-HCl, $1.5 \mathrm{mM}$ $\mathrm{Mg}^{2+}, 200 \mu \mathrm{M}$ of each dNTP and 1.25 U Taq DNA Polimerase), 30 pmol of each primer and $10 \mu \mathrm{l}$ of DNA. Initial denaturation was performed at $94^{\circ} \mathrm{C}$ for 5 minutes and, in the end, extension at $72^{\circ} \mathrm{C}$ for 10 minutes. Forty cycles divided in three phases were as follows: denaturation at $94^{\circ} \mathrm{C}$ for 60 seconds, hybridization at $55^{\circ} \mathrm{C}$ for 60 seconds and extension at $72^{\circ} \mathrm{C}$ for 45 seconds.

PCR for the differentiation of strain origin was carried in Brucella abortus positive samples, using the primers eri 1- 5' TTGGCGGCAAGTCCGTCGGT 3' and eri 2- 5'CCCAGAAG CGAGACGAAACG 3' (17). Primer eri 3- 5' CGCCATGTTAG CGGCGGTGA 3’, described by Bricker and Halling (4) was also used, together with eri 1 in the hemi-nested PCR. Modified amplification was performed with $14 \mu \mathrm{l}$ of ultrapure water (Millipore), $20 \mu \mathrm{l}$ of Master Mix - Eppendorf (50 mM KCl, 30 mM Tris- $\mathrm{HCl}, 1.5 \mathrm{mM} \mathrm{Mg}^{2+}, 200 \mu \mathrm{M}$ of each dNTP and $1.25 \mathrm{U}$ of Taq DNA Polimerase), $30 \mathrm{pmol}$ of each primer (eri 1 and eri 2 in the first reaction and eri 1 and eri 3 in nested-PCR) and $10 \mu \mathrm{l}$ of DNA. Both in PCR and nested PCR, before the temperature cycle, denaturation was carried out at $94^{\circ} \mathrm{C}$ for 10 minutes and extension at $72^{\circ} \mathrm{C}$ for 10 minutes. In the first reaction, 35 cycles were performed in three phases: denaturation at $94^{\circ} \mathrm{C}$ for 60 seconds, hybridization at $57^{\circ} \mathrm{C}$ for 120 seconds and extension at $72^{\circ} \mathrm{C}$ for 120 seconds. In nested PCR, 30 cycles were employed: denaturation at $94^{\circ} \mathrm{C}$ for 60 seconds, hybridization at $59^{\circ} \mathrm{C}$ for 60 seconds and extension at $72^{\circ} \mathrm{C}$ for 45 seconds. 
Amplifications were carried out in a Peltier Thermal Cycler-200 (MJ Research) and the analysis of the amplified products was performed by means of electrophoresis in $1.3 \%$ agarose gel with TBE $0.5 \mathrm{X}$ running buffer $(0.045 \mathrm{M}$ TRIS-Borate and $1 \mathrm{mM}$ of EDTA ph 8.0). Gel was stained with ethidium bromide and submitted to constant voltage of $6-7 \mathrm{~V} / \mathrm{cm}$.

\section{Proof of primer specificity}

All standard strains were tested in all PCR reactions described in this trial.

Evaluation of PCR detection threshold in cheese experimentally contaminated with different concentrations (CFU) of Brucella abortus field and B19 vaccinal strains

PCR detection thresholds were obtained by means of the experimental contamination of suspensions of cheese samples negative in both PCR and microbiological culture. Tubes with one mililiter of suspension of cheese $25 \%$ (w/v) was contaminated either with $1 \mathrm{CFU}$ of vaccinal strain B19 or $1 \mathrm{CFU}$ of Brucella abortus field strain (initial concentration of $1 \mathrm{CFU} /$ $\mathrm{mL}$ ). The suspensions were then subjected to tenfold serial dilutions until $10^{-10} \mathrm{CFU} / \mathrm{mL}$.

\section{Agreement between PCR and microbiological culture for Brucella spp.}

Agreement between microbiological culture and PCR for Brucella abortus was measured by means of the Kappa indicator (19).

\section{RESULTS}

Primers used in the trial had their specificity confirmed: $\mathrm{B}_{4}$ and $\mathrm{B}_{5}(1)$ amplified a $223 \mathrm{bp}$ fragment from the six Brucella species and from vaccinal strains B19 and RB51; BAB and IS 711 (3) amplified a 498 bp fragment only in strain 544 of Brucella abortus and in vaccinal strains B19 and RB51; eri 1 and eri 2 (17) amplified a $1.063 \mathrm{bp}$ fragment in the field strains and in the vaccinal strain RB51, as well as a 361 bp fragment in strain B19. In hemi-nested PCR there is amplification of $240 \mathrm{bp}$ fragments for all Brucella strains, except B19. Therefore, for B19 strains there is no hybridization site for eri 3 , but primers eri 1 and eri 2 still amplified $361 \mathrm{bp}$ fragments, since there is the addition of primer eri 1 and amplicons from the first reaction, to hemi-nested PCR reagents.

Table 1 shows the detection thresholds obtained in the analysis of cheese experimentally contaminated with serial dilutions of B19 and field strains of Brucella abortus. Figs. 1 and 2 confirm the detection threshold of PCR and nested PCR in the differentiation of the origin of the strain in samples contaminated with B19 and field strain, respectively.

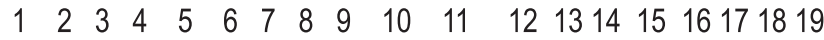

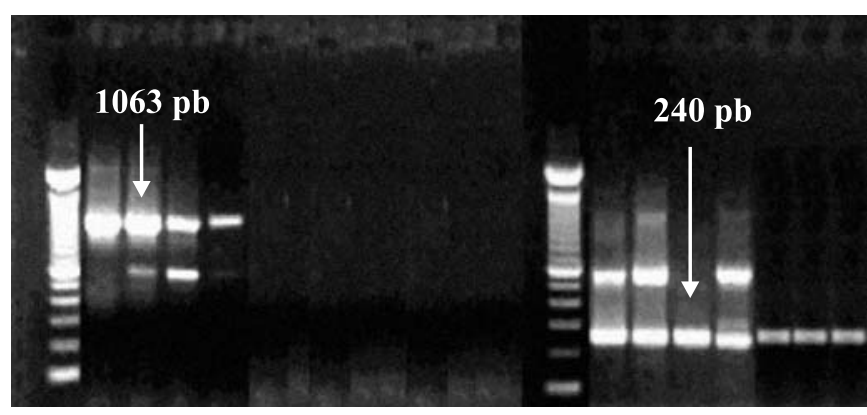

Figure 1. PCR using primers eri 1 and eri 2 (SANGARI; GARCÍA-LOBO; AGÜERO, 1994) and nested-PCR (n-PCR) using primers eri 1 and eri 3 (BRICKER; HALLING, 1995) applied to cheese experimentally contaminated with B19 strain. (1) Molecular standard $100 \mathrm{bp}$; (2) $10^{\circ} \mathrm{CFU} / \mathrm{mL}$; (3) $10^{-1} \mathrm{CFU} / \mathrm{mL}$; (4) $10^{-2} \mathrm{CFU} / \mathrm{mL}$; (5) $10^{-3} \mathrm{CFU} / \mathrm{mL}$; (6) $10^{-4} \mathrm{CFU} / \mathrm{mL}$; (7) $10^{-5} \mathrm{CFU} /$ $\mathrm{mL}$; (8) $10^{-6} \mathrm{CFU} / \mathrm{mL}$; (9) $10^{-7} \mathrm{CFU} / \mathrm{mL}$; (10) $10^{-8} \mathrm{CFU} / \mathrm{mL}$; (11) $10^{-9}$ $\mathrm{CFU} / \mathrm{mL}$; (12) $10^{-10} \mathrm{CFU} / \mathrm{mL}$; (13) Molecular standard $100 \mathrm{bp}$; (14) n-PCR $10^{-5} \mathrm{CFU} / \mathrm{mL}$; (15) n-PCR $10^{-6} \mathrm{CFU} / \mathrm{mL}$; (16) n-PCR $10^{-7} \mathrm{CFU} / \mathrm{mL}$; (17) n-PCR $10^{-8} \mathrm{CFU} / \mathrm{mL}$; (18) n-PCR $10^{-9} \mathrm{CFU} / \mathrm{mL}$; (19) n-PCR $10^{-10} \mathrm{CFU} / \mathrm{mL}$.

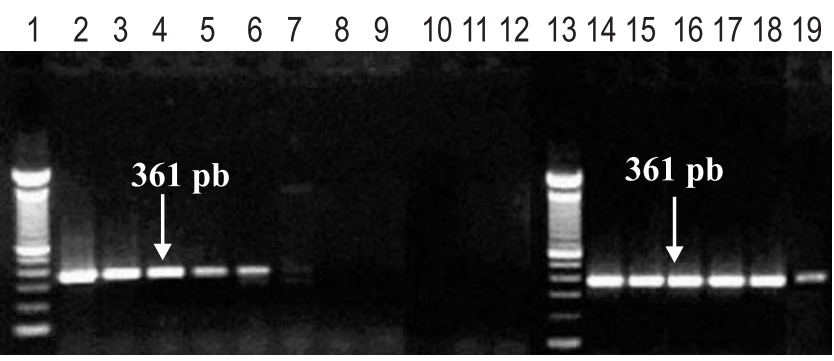

Figure 2. PCR using primers eri 1 and eri 2 (SANGARI; GARCÍA-LOBO; AGÜERO, 1994) and nested-PCR (n-PCR) using primers eri 1 and eri 3 (BRICKER; HALLING, 1995) applied to cheese experimentally contaminated with field strain. (1) Molecular standard $100 \mathrm{bp}$; (2) $10^{\circ} \mathrm{CFU} / \mathrm{mL}$; (3) $10^{-1} \mathrm{CFU} / \mathrm{mL}$; (4) $10^{-2} \mathrm{CFU} / \mathrm{mL}$; (5) $10^{-3} \mathrm{CFU} / \mathrm{mL}$; (6) $10^{-4} \mathrm{CFU} / \mathrm{mL}$; (7) $10^{-5} \mathrm{CFU} /$ $\mathrm{mL}$; (8) $10^{-6} \mathrm{CFU} / \mathrm{mL}$; (9) $10^{-7} \mathrm{CFU} / \mathrm{mL}$; (10) $10^{-8} \mathrm{CFU} / \mathrm{mL}$; (11) $10^{-9}$ $\mathrm{CFU} / \mathrm{mL}$; (12) $10^{-10} \mathrm{CFU} / \mathrm{mL}$; (13) Molecular standard $100 \mathrm{bp}$; (14) n-PCR $10^{-4} \mathrm{CFU} / \mathrm{mL}$; (15) n-PCR $10^{-5} \mathrm{CFU} / \mathrm{mL}$; (16) n-PCR $10^{-6} \mathrm{CFU} / \mathrm{mL}$; (17) n-PCR $10^{-7} \mathrm{CFU} / \mathrm{mL}$; (18) n-PCR $10^{-8} \mathrm{CFU} / \mathrm{mL}$; (19) n-PCR $10^{-9} \mathrm{CFU} / \mathrm{mL}$; (20) n-PCR $10^{-10} \mathrm{CFU} / \mathrm{mL}$. 
Table 2. Results for Brucella spp. positive cheese samples, for determination of B. abortus species and hemi-nested PCR (eri 1/ eri 2 ; and eri 1/ eri 3 ) for differentiation of origin of strain.

\begin{tabular}{|c|c|c|c|c|c|c|c|c|}
\hline \multirow[b]{2}{*}{ Sample } & \multirow[b]{2}{*}{ Cheese type } & \multirow[b]{2}{*}{ Origin } & \multirow[b]{2}{*}{$\begin{array}{l}\text { Microbiologica } \\
\text { culture }\end{array}$} & \multicolumn{4}{|c|}{ PCR } & \multirow[b]{2}{*}{ Conclusion } \\
\hline & & & & $\begin{array}{c}\text { Brucella spp. } \\
\left(\mathrm{B}_{4} / \mathrm{B}_{5}\right)\end{array}$ & $\begin{array}{c}\text { B. abortus } \\
\text { (BAB/IS 711) }\end{array}$ & eri 1 / eri 2 & eri 1 / eri 3 & \\
\hline C267 & 1 & $\mathrm{MG}$ & negative & positive & positive & negative & $361 \mathrm{pb}$ & B19 \\
\hline $\mathrm{C} 270$ & 1 & MG & negative & positive & positive & $361 \mathrm{pb}$ & & B19 \\
\hline $\mathrm{C} 265$ & 1 & MG & negative & positive & positive & negative & $240 \mathrm{pb}$ & Field \\
\hline C291 & 1 & MG & negative & positive & positive & negative & $361 \mathrm{pb}$ & B19 \\
\hline C268 & 1 & $\mathrm{MG}$ & negative & positive & positive & negative & $361 \mathrm{pb}$ & B19 \\
\hline C238 & 1 & MG & negative & positive & positive & negative & $361 \mathrm{pb}$ & B19 \\
\hline C269 & 1 & MG & negative & positive & positive & negative & $361 \mathrm{pb}$ & B19 \\
\hline C94 & 1 & MG & negative & positive & positive & $361 \mathrm{pb}$ & & B19 \\
\hline $\mathrm{C} 15$ & 2 & MG & negative & positive & positive & negative & $240 \mathrm{pb}$ & Field \\
\hline C211 & 2 & MG & negative & positive & positive & negative & $361 \mathrm{pb}$ & B19 \\
\hline C39 & 1 & MG & negative & positive & positive & negative & $361 \mathrm{pb}$ & B19 \\
\hline $\mathrm{C} 40$ & 1 & MG & negative & positive & positive & negative & $361 \mathrm{pb}$ & B19 \\
\hline C6 & 1 & MG & negative & positive & positive & negative & $361 \mathrm{pb}$ & B19 \\
\hline C235 & 1 & SP & negative & positive & positive & $361 \mathrm{pb}$ & & B19 \\
\hline $\mathrm{C} 18$ & 1 & SP & negative & positive & positive & $361 \mathrm{pb}$ & & B19 \\
\hline $\mathrm{C} 21$ & 1 & SP & negative & positive & positive & negative & $361 \mathrm{pb}$ & B19 \\
\hline C50 & 1 & SP & negative & positive & positive & $1063 \mathrm{pb}$ & & Field \\
\hline $\mathrm{C} 16$ & 1 & SP & negative & positive & positive & negative & $361 \mathrm{pb}$ & B19 \\
\hline C19 & 1 & SP & negative & positive & positive & negative & $361 \mathrm{pb}$ & B19 \\
\hline $\mathrm{C} 22$ & 1 & SP & negative & positive & positive & negative & $361 \mathrm{pb}$ & B19 \\
\hline C44 & 1 & $\mathrm{SP}$ & negative & positive & positive & $361 \mathrm{pb}$ & & B19 \\
\hline $\mathrm{C} 121$ & 1 & SP & negative & positive & positive & $361 \mathrm{pb}$ & & B19 \\
\hline $\mathrm{C} 123$ & 1 & SP & negative & positive & positive & negative & $240 \mathrm{pb}$ & Field \\
\hline C182 & 1 & SP & negative & positive & positive & $1063 \mathrm{pb}$ & & Field \\
\hline C190 & 1 & SP & negative & positive & positive & $361 \mathrm{pb}$ & & B19 \\
\hline $\mathrm{Cl}$ & 2 & SP & negative & positive & positive & negative & $240 \mathrm{pb}$ & Field \\
\hline $\mathrm{C} 13$ & 2 & SP & negative & positive & positive & $361 \mathrm{pb}$ & & B19 \\
\hline $\mathrm{C} 24$ & 1 & SP & negative & positive & positive & negative & $361 \mathrm{pb}$ & B19 \\
\hline $\mathrm{C} 28$ & 2 & SP & negative & positive & positive & negative & $361 \mathrm{pb}$ & B19 \\
\hline C30 & 2 & SP & negative & positive & positive & $361 \mathrm{pb}$ & & B19 \\
\hline $\mathrm{C} 4$ & 1 & SP & negative & positive & positive & negative & $240 \mathrm{pb}$ & Field \\
\hline C47 & 2 & SP & negative & positive & positive & negative & $361 \mathrm{pb}$ & B19 \\
\hline C51 & 1 & SP & negative & positive & positive & negative & $361 \mathrm{pb}$ & B19 \\
\hline C54 & 1 & SP & negative & positive & positive & $361 \mathrm{pb}$ & & B19 \\
\hline C55 & 1 & $\mathrm{SP}$ & negative & positive & positive & $361 \mathrm{pb}$ & & B19 \\
\hline C59 & 2 & SP & negative & positive & positive & $361 \mathrm{pb}$ & & B19 \\
\hline C9 & 1 & SP & negative & positive & positive & $361 \mathrm{pb}$ & & B19 \\
\hline
\end{tabular}

Legend: 1= Minas frescal type cheese; 2= cured Minas type cheese; SP = São Paulo; MG = Minas Gerais.

The 192 samples studied were negative for Brucella spp. in the bacteriological culture, but were contaminated by other microorganisms such as Streptococcus spp., Staphylococcus spp., fecal coliforms and Pseudomonas aeruginosa. In the PCR for detection of Brucella spp. DNA, 37 samples (19.27\%) were positive. From these, 29/141 (20.56\%) samples of Minas frescal cheese and $8 / 51$ (15.68\%) of cured Minas type cheese were positive. From the samples collected in São Paulo, 19.2\% (24/ 125) were positive for Brucella abortus, and from the Minas Gerais samples, 19.4\% (13/67). All 37 samples (100\%) positive for Brucella spp. were diagnosed as Brucella abortus by means of PCR. From these, $30(81.08 \%)$ were differentiated as being 
vaccinal strains (B19), and seven (18.92\%) as field strains. Nested PCR enabled the differentiation of the origin of 22/37 (59.45\%) samples (Table 2).

\section{DISCUSSION}

In the present trial, the extraction of DNA with DNAzol reagent together with the amplification protocol of PCR reactions for Brucella abortus and for the differentiation of the strain led to low detection thresholds.

Ewalt and Bricker (8) described a PCR assay for the differentiation of B19 with the amplification of 178 bp fragments for all Brucella spp. strains except B19, which result is the absence of signal. Thus, one can speculate that the absence of amplified fragments is related to the real presence of B19 in the sample, but it can be due to many factors involved in the DNA extraction or PCR procedures (e.g. presence of inhibitory substances, degradation, abscence or low yeld of DNA template, etc.). We present an alternative approach assuring that there will be a signal from both field or vaccinal B19 strains. So, if there is no signal in the reaction with primers eri 1 and eri 2 , hemi-nested PCR should be accomplished for higher analytical sensitivity, providing a signal even for field strains and RB51 (240 bp) or B19 (361 bp). Standardization of hemi-nested PCR with primers eri 1 and eri 3 enabled the differentiation of the strain in most of the analyzed samples (22/37).

Among the 192 samples considered to be negative in Brucella spp microbiological culture, PCR produced positive results in 29/141 (20.56\%) samples of Minas frescal cheese and in 8/51 (15.69\%) samples of cured Minas type cheese. Agreement between techniques was low, probably due to differences between them. While microbiological culture depends on organism viability, quality of the sample and time between collection and analysis, DNA detection by means of PCR does not depend on these factors. In this technique, non-viable microorganisms, contamination of the sample with other microorganisms or delays in the analysis do not affect the results. The same index was reported by Tantillo et al. (18), who studied the presence of Brucella spp. in 46 cheese samples (goat and sheep cheese) by means of microbiological culture and PCR.

Differentiation of strain origin in dairy products showed the occurrence of the vaccinal strain B19 in 30/37 (81.08\%) of the positive samples. Besides the presence of vaccinal antibodies in adult females, B19 strain may persistently infect the uterus, and depending on the age and reproductive status of the female at vaccination, and on the dose and vaccination method used, constant or intermittent shedding of the microorganism in milk may occur. Even in animals that are vaccinated at the recommended age (3 to 8 months old) abortion or persistent infection may occur after vaccination, with shedding of the microorganism in milk.
The present trial was efficient in the standardization of sensitive and specific molecular techniques that may be applied to dairy products for the detection of Brucella spp., as well as for the differentiation of vaccinal strain B19 and other Brucella strains, aiding brucellosis control programs such as the PNCEBT. Results set a warning for public health and to the fact that incorrect vaccination and / or inadequate management that occur in illegal dairy production should receive special attention from governmental agencies for the brucellosis control program effectively to reach its objectives.

\section{ACKNOWLEDGEMENTS}

This study was financially supported by FAPESP - Fundação de Amparo a Pesquisa do Estado de São Paulo - research project \#2002/07905-4.

\section{RESUMO}

\section{Deteç̧ão de DNA de Brucella abortus em queijos clandestinos provenientes de São Paulo e Minas Gerais e diferenciação da vacina $B 19$ pela reação da polimerase em cadeia (PCR)}

Foram analisadas 192 amostras de queijo clandestinas provenientes de várias regiões do Estado de São Paulo e Minas Gerais, Brasil, para isolamento e detecção de DNA de Brucella spp. através das técnicas de cultivo microbiológico e reação da polimerase em cadeia (PCR), respectivamente. Para as amostras positivas foi pesquisada a ocorrência da espécie Brucella abortus (biovares 1, 2 e 4), além da diferenciação do DNA em cepa vacinal B19 ou de campo por PCR. Não foi possível isolar o microrganismo de nenhuma amostra, porém, na PCR, 37 amostras $(19,27 \%)$ foram positivas na reação com primers gênero específicos e destas, todas (100\%) foram comprovadas como sendo Brucella abortus. A diferenciação da cepa revelou que $30 / 37$ amostras $(81,08 \%)$ eram cepa vacinal B19 e sete $(18,92 \%)$ eram cepas de Brucella abortus de campo. Os resultados mostraram uma maior sensibilidade diagnóstica da PCR em relação ao cultivo microbiológico, e a padronização da reação de diferenciação da cepa em vacinal ou campo permitiu que todas as amostras positivas para Brucella abortus fossem analisadas, sendo uma metodologia confiável e aplicável a infecções naturais pelo microrganismo.

\section{Palavras-chave: Brucella abortus, B19, PCR, queijo}

\section{REFERENCES}

1. Baily, G.G.; Krahn, J.B.; Drasar, B.W.; Stoker, N.G. (1992). Detection of Brucella melitensis and Brucella abortus by DNA amplification. J. Trop. Med. Hyg., 95(4), 271-275. 
2. Brasil. Ministério da Agricultura. Secretaria Nacional de Defesa Agropecuária. (2004). Programa Nacional de Controle e Erradicação da Brucelose e Tuberculose Animal. http://www.agricultura.gov.br

3. Bricker, B.J.; Halling, S.M. (1994). Differentiation of Brucella abortus bv. 1, 2 and 4, Brucella melitensis, Brucella ovis, and Brucella suis bv. 1 by PCR. J. Clin. Microbiol., 32(11), 2660-2666.

4. Bricker, B.J.; Halling, S.M. (1995). Enhancement of the Brucella AMOS PCR assay for differentiation of Brucella abortus vaccine strains S19 and RB51. J. Clin. Microbiol., 33(6), 1640-1642.

5. Bricker, B.J. (2002). PCR as a diagnostic tool for brucellosis. Vet. Microbiol., 90(1-4), 435-446.

6. Chomczynski, P. (1993). A reagent for the single-step simultaneous isolation of RNA, DNA and proteins from cells and tissue samples. Biotechniques, 15, 532-537.

7. Corbel, M.J. (1997). Brucellosis: an overview. Emerg. Inf. Dis., 3(2), 213-221.

8. Ewalt, D.R.; Bricker, B. (2000). Validation of the abbreviated Brucella AMOS PCR as a rapid screening method for differentiation of Brucella abortus field strain isolates and the vaccine strains, 19 and RB51. J. Clin. Microbiol., 38(8), 3085-3086.

9. Farina, E.M.M.Q.; Jank, M.S.; Nassar, A.M.; Ribeiro, F.A.F. (2000). Leite clandestino: um problema real! Boletim do Leite, v.7, n.81. http://cepea.esalq.usp.br

10. Garcia-Carrillo, C. (1990). Animal and human brucellosis in the Americas. Office International des Epizooties, Paris.
11. Leyla, G.; Kadri, G.; Ümran, O.K. (2003). Comparison of polymerase chain reaction and bacteriological culture for the diagnosis of sheep brucellosis using aborted fetus samples. Vet. Microbiol., 93(1), 5361 .

12. Metcalf, H.E.; Luchsinger, D.W.; Ray, W.C. (1994). Brucellosis. In: Beran, G.W.; Seele, J. H. (Ed). Handbook series in zoonoses: section A, bacterial, rickettsial, chlamydial, and mycotic. CRC Press, Boca Raton, p.9-39.

13. OIE. Bovine brucellosis. (2004). In: Manual of Diagnostic Tests and Vaccines for Terrestrial Animals.

14. Paulin, L.M.S.; Ferreira Neto, J.S. (2003). O combate à brucelose bovina. Situação brasileira. Funep, Jaboticabal.

15. Poester, F.P.; Gonçalves, V.S.P.; Lage, A.P. (2002). Brucellosis in Brazil. Vet. Microbiol., 90(1-4), 55-62.

16. Quinn, P.J.; Carter, M.E.; Markey, B.; Carter, G.R. (1996). Clinical Veterinary Microbiology. Wolfe Publishing, London.

17. Sangari, F.J.; Agüero, J.; Garcia-Lobo, J.M. (2000). The genes for erythritol catabolism are organized as an inducible operon in Brucella abortus. Microbiology, 146, 487-495.

18. Tantillo, G.; Di Pinto, A.; Vergara, A.; Buonavoglia, C. (2001). Polymerase chain reaction for the direct detection of Brucella spp. in milk and cheese. J. Food Prot., 64(2), 164-167.

19. Thrusfield, M. (1995). Diagnostic testing. In:Thrusfield, M. Veterinary Epidemiology. The University Press Great Britain, p.266285. 